\title{
What is a Good Research Project?
}

\author{
Brian Paltridge \\ University of Sydney, Australia
}

\begin{abstract}
This paper discusses characteristics of a "good research project." It also discusses strategies for developing a research proposal. This includes suggestions for how to choose and focus a research topic as well as how to refine a research question. Details to include in a research proposal as well as the very specific areas that a research proposal needs to address are discussed. Questions to guide the design of the research proposal are also presented. The paper concludes with the discussion of a sample study which contains the characteristics of a good research project referred to in the paper. Suggestions for further reading on the development of a research project are also provided.
\end{abstract}

A key feature of a good research project is that it has never been done before; that is, it is in some way origina/ in the sense that it is not aiming to find out something people in the field already know. The project also needs to be worth doing. It is, then, important to consider the value and relevance of the project as there are many things that might be capable of being done that are not worth doing. A good research project also needs to be feasible and manageable within the time frame available for it, with the resources that are available for the project and by the person (or people) who will be carrying out the study. Thus, a project that may take three to four years, as with a PhD project, will be much too ambitious if there is only a year available to carry out and complete the study. There may also be financial resources required for the project, such as airfare and hotel costs, that without them, the project may not be able to proceed. It is also important to consider whether the people who wish to carry out the project have the theoretical background and methodological skills that the proposed study requires. For example, if the study is a conversation analysis project, the people carrying out the study need to know how to do conversation analysis. If the study requires some kind of statistical treatment, the researcher (or researchers) needs to be able to do this. It is also important that the topic of the research be of interest to a wider audience, such as the international readership of a journal, as one of the aims of conducting research is disseminating it to a wider audience. Connected to this is whether the completed project is likely to lead to some kind of publication, such as a journal article or a book, so that the research is able to contribute to the development of the discipline in which it is located.

\section{Developing a Research Proposal}

There are a number of important steps to go through in developing a research proposal. A good place to start with this is by drawing up a shortlist of topics that might be worth investigating. It is then a good idea to take this list to someone who has had experience in carrying out research (such as a colleague or potential mentor) to get advice on which topic, in their view, is the best one to proceed with. The next thing for researchers to do is to formulate a general question that

Language Education in Asia, 2014, 5(1), 20-27. http://dx.doi.org/10.5746/LEiA/14/V5/I1/A03/Paltridge 
the research will answer and, from there, focus the question. This stage of the process often causes new researchers the most trouble, so people who are new to research should not rush this stage and should take as much time as needed to do this. In short, the question has to be both worthy and answerable. A question may be worth asking but impractical to answer, or answerable but not worth researching. The study, thus, needs to have a question that both has value and is answerable in terms of the proposed methodology and the question's capability.

Table 1 provides more detailed advice on ways to refine a research question.

\section{Table 1}

\section{Ways to Refine a Research Question (based on Stevens \& Asmar, 1999, p. 17)}

- Read broadly and widely and to find a subject about which you are passionate. Immerse yourself in the literature, use your library, read the abstracts of other recent theses and dissertations, check theses on the web. For example: http://www.ndltd.org/

- Narrow your focus to a single question: be disciplined and not over-ambitious

- Be prepared to change or modify your question if necessary

- Be able to answer the question "Why am I doing this project?" (and not a different one)

- Read up-to-date materials - ensure that your idea is achievable and no one else has done or is doing it

- Work through the implications of your research question: consider existing materials and ideas on which it is based, check the logic, spell out methods to be used

- Condense your research question into two sentences: write it down, with pride, above your working area. Change the question if needed.

- Ask yourself: What will we know at the end that we did not already know?

Table 2 shows how a Chinese student who was a beginning researcher started from a very general topic and moved from there to a more narrowly focused research question that had value and was answerable. In his particular case, he was studying at a university outside China but was interested in how a communicative approach to language teaching could be implemented in university classes in his country. As he was not living in China, he could not get any firsthand data that he could use for his study. He did, however, have a set of textbooks with him that everyone in his university used to teach English. The researcher was also particularly interested in the teaching of listening so he brought the resources and the interest he had together by looking at how the teaching of listening was approached in Chinese university text books and comparing this with communicatively oriented textbooks published in English-speaking countries. He, thus, moved from a question that was worth asking but not, in his current situation, capable of being answered to one that was also worth asking and also capable of being done. 


\section{Table 2}

\section{Choosing and Focusing a Research Topic: An Example}

Choosing a topic

Communicative language teaching in China

Choosing a question

Communicative language teaching in Chinese universities: Is it really possible?

Focusing the question

The place of listening in the communicative classroom: An East-West comparison

Narrowing the focus of the question

Focusing on listening in EFL coursebooks: An East-West comparison

Once the research question has been decided, a decision needs to be made about what data needs to be collected to answer the question, where and how it might be collected, and how the data might be analysed. An initial research plan can be drawn up from here. It is important, at the same time, to read enough in order to decide whether the proposed project is on the right track. To do this, previous research on the topic needs to be examined in order to see what research has already been carried out on the proposed topic as well as how this research was carried out. It is also essential to think about ethical implications of the research in terms of what permissions need to be obtained to carry out the research, and what guarantees of anonymity can be given to the people (if any) involved in the research.

\section{The Structure of a Research Proposal}

The next stage is to write a detailed research proposal. This should include definitions of key constructs in the proposal (such as "negotiation of meaning" or "willingness to communicate") that would enable someone else reading it (and in turn the completed research) to understand what exactly is meant by these terms in the research.

Table 3 shows the typical structure of a research proposal and the purpose of each of the sections of the proposal. 


\section{Table 3}

The Typical Structure of a Research Proposal (adapted from Paltridge \& Starfield, 2007)

\begin{tabular}{|c|c|}
\hline Section & Purpose \\
\hline Title & To summarise, in a few words, what the research will be about \\
\hline $\begin{array}{l}\text { Relevant background } \\
\text { literature }\end{array}$ & $\begin{array}{l}\text { To demonstrate the relationship between the proposed study and what } \\
\text { has already been done in the particular area; that is, to indicate the "gap" } \\
\text { that the study will fill }\end{array}$ \\
\hline Research question(s) & $\begin{array}{l}\text { To provide an explicit statement of what the study will investigate, i.e., the } \\
\text { questions the study will answer or the hypotheses it will test }\end{array}$ \\
\hline Definitions of terms & $\begin{array}{l}\text { To provide the meaning of the key terms that have been used in the } \\
\text { research question(s) }\end{array}$ \\
\hline $\begin{array}{l}\text { Research } \\
\text { methodology }\end{array}$ & $\begin{array}{l}\text { To provide an overview of the research approach that will be employed in } \\
\text { the study, data that will be collected, how it will be analysed, etc. }\end{array}$ \\
\hline $\begin{array}{l}\text { Anticipated problems } \\
\text { and limitations }\end{array}$ & $\begin{array}{l}\text { To show awareness of the limitations of the study, what problems may be } \\
\text { met in carrying it out, and how they will be dealt with }\end{array}$ \\
\hline $\begin{array}{l}\text { Significance of the } \\
\text { research }\end{array}$ & To say why the study is worth carrying out \\
\hline $\begin{array}{l}\text { Resources required / } \\
\text { Budget }\end{array}$ & $\begin{array}{l}\text { To say what resources the research will require and what costs may be } \\
\text { anticipated in carrying out the study }\end{array}$ \\
\hline Ethics & $\begin{array}{l}\text { To provide a statement as to how participants will be advised of the overall } \\
\text { nature of the study and how informed consent will be obtained from them }\end{array}$ \\
\hline Timetable & To give a working plan for carrying out and completing the study \\
\hline References & To provide detailed references and bibliographic support for the proposal \\
\hline Appendix & $\begin{array}{l}\text { To provide examples of materials that might be used, or adapted, in the } \\
\text { study }\end{array}$ \\
\hline
\end{tabular}

\section{Details to Include in a Research Proposal}

A research proposal is expected to include a focused research question that has value and is answerable. It should also contain the key terms in the question and their definitions so that during the study, these items can be observed. The proposal should include key research which has already been carried out on the particular topic. The main issues or controversies which surround the problem should be discussed, as well as any gaps in the previous research on the topic. It is also important to show how the previous research is relevant to the study being proposed.

The study needs to select a research approach that is an appropriate for the particular question or problem that will be investigated. A well defined list of procedures that will be followed in carrying out the research needs to be described. This includes both the method of data collection and its analysis. There should be an indication of how the study's participants (or data) will be selected for the study. It is also helpful to plan for a pilot study so that the research instruments can be trialed and evaluated.

It is also important to say why the study is significant; that is, why it is worth doing. Ethical issues, if there are any, need to be discussed. This includes whether informed consent needs to be obtained for the study, and if this is the case, how this will be done. It is also helpful to include a proposed timetable for the research as this will give an indication as to how realistic the proposal actually is. A budget statement is also important as this will give an indication of 
how realistic the proposal is in terms of financial requirements and whether the research might need to be adapted in the light of these.

Nunan (1992) provides a useful set of questions for guiding the design of a research proposal. Each of these questions needs to be considered in the development and refinement of the proposal. These are shown in Table 4.

\section{Table 4}

Questions to Guide the Design of a Research Proposal (Nunan, 1992, p. 227)

\begin{tabular}{ll}
\hline Area & Questions \\
\hline Question & Is the question worth investigating? \\
& Is the question feasible? \\
& What are the constructs underlying my question? \\
& How will these be operationalised? \\
Design & Does the question suggest an experimental or a non-experimental design? \\
Method & What methods are available for investigating the question? \\
& Which of these are feasible, given available resources and expertise? \\
Analysis & Is it possible to use more than one data collection method? \\
& Do I have the skills to carry out the kind of analysis I propose? \\
\hline
\end{tabular}

\section{A Sample Study}

Nakane's (2007) examination of silence in Japanese students' interactions in their regular university courses in an English medium university where there was mix of native and nonnative speaker students of English is an example of a study that has many of the characteristics of a good research project described earlier in this paper. In her study, Nakane looked at the Japanese students' spoken interactions in the university classrooms as well as the other students, and lecturers' perceptions of the Japanese students' interactions. She combined the techniques of conversation analysis with ethnographic data in order to obtain multiple perspectives on the issue she wanted to explore.

Research question. The aim of Nakane's study was to examine the communication problems faced by Japanese students in their classes. She also wanted to see whether there were characteristic discourse patterns which could be sources of their communication problems. This question drew from her own experience as an English teacher in Japan, where she had begun to wonder how Japanese students would cope with academic interactions in an Englishspeaking country. She discovered from her reading of the research literature that we know very little about communication problems these students encounter and what causes communication problems for them. Her study, thus, was worth doing, capable of being done, and had not been done before. As such, it would fill an important gap in previous research about second language students' interactional patterns, and what they mean, in university classroom settings.

Methodology. The question Nakane proposed suggested a non-experimental, rather than experimental design as she had an open question she wanted to explore rather than a hypothesis she wanted to test. She used more than one data collection method for her study in order to give greater depth to her study. Nakane recorded classroom interactions which 
included the Japanese students, conducted individual interviews, focus group discussions, and administered questionnaires. Each of these data collection methods were within her expertise and were permitted by the institution where she was carrying out the study. Nakane combined this data with three case studies which drew on video and audio recordings, field notes, and artifacts from her classroom observations. The case studies used stimulated recall interviews and follow-up interviews with the Japanese students, fellow English-speaking students, and their teachers. A large-scale survey that had been independently carried out at another university was also used as a data source for the study. Nakane also collected data from classrooms in Japan in order to make a comparison between her observations of the English-medium classrooms and how Japanese students might typically behave in a similar kind of setting in Japan. The Japanese data consisted of video recordings, field notes, and artifacts from the Japanese classrooms.

Data analysis. Nakane's study involved an interpretive analysis of her data. She carried out a conversation analysis of the English classroom data. She also carried out a content analysis of the interview and stimulated recall data which allowed categories and sub-categories to emerge from the data, rather than using a set of pre-determined categories as the starting point for her analysis. This was important for her study as she didn't want to base her analysis on any previous conceptions she had as to why the students had difficulty communicating in their classes. The video and audio material were coded following patterns that had emerged from the students' and staff's self-reports in the stimulated recall interviews and the follow-up interviews. The conversation analysis component of the data was counter-checked by another analyst who was familiar with the conventions and expectations of conversation analysis to increase the reliability of her study.

Nakane also considered the results of her study in relation to other issues such as teacherstudent interactional modes, teacher control of classroom discourse, timing in the taking of turns, the Japanese students' perceptions of politeness, and, in particular, the hierarchy-oriented politeness system they were used to in their interactions with teachers in Japan. She also considered her findings in relation to the issues of the Japanese students' language proficiency and their different schema, or interpretive frames, for classroom interactions.

Results of the study. The silence of the Japanese students was one of the major problems in the classrooms. Nakane also found that gaps in assumptions about classroom communication between the Japanese students, fellow English-speaking students, and their lecturers contributed to the students' silence in each of her three cases. The Japanese students' silence in class, she suggested, seemed to prevent the establishment of rapport between them and their lecturers. She also found there was a conflict between the lecturers' view of the Japanese students' personalities (for example, as being shy) when this was not the case for the students outside of the classroom. The students' silence in class was interpreted, she found, as a negative attitude and lack of commitment to their studies, where in fact, for one of the students she examined, this was not at all the case. Her initial feelings about what the issues might have been for these students in their classes, then, proved to be correct, although she needed to carry out her study to find this out.

Awareness of limitations. Nakane is well aware of the limits to the claims that can be made on the basis of her study and argues for the accumulation of further data and analyses of the kind that she had carried out. In particular, she points to the need to further explore the types and aspects of silence that she observed. She argues that these analyses need to be at both the micro and the macro levels; that is, by a detailed analysis of the actual interactions as well as a broader analysis of the situation and circumstances that surround the interactions. She also 
suggests the examination of student interactions in different types of study situations to see to what extent students' interactions in these situations are similar to, or different from, the interactions that she observed. She suggests looking at the reverse kind of situation as well; that is, looking at the interactions of English-speaking students in Japanese university settings to see to what extent the English-speaking students' experiences in a Japanese university classroom are similar to, or different from, the Japanese students' interactions that she examines in her study.

Commentary. A particular strength of Nakane's study was the multiple perspectives she took on her research question in order to provide both validity and depth to her research findings. These multiple data sources provided for a detailed and fine-grained analysis of the research questions. The project showed a good understanding of the importance of triangulation in this sort of study by combining different perspectives on the research questions that she examined. Her ethnographic data provided insights into her findings that would not have been possible by looking at the spoken interactions alone. Nakane's study is an example of a project that was well conceived, well designed, and well carried out. Further, it provided answers to questions that are of value to both university teaching staff and to students and that may help, in the future, to provide solutions to the kinds of communication problems the students in her study were experiencing.

\section{Conclusion}

This paper has aimed to outline some of the key characteristics of good research projects and illustrate those characteristics with a sample study. There is, of course, much more that could be said on this topic than has been outlined in this paper. Bell's (2010) Doing Your Research Project, for example, is a very helpful book for beginning researchers to consult for advice on developing a research project. Chapter Two of Bell's book discusses planning a research project, selecting a topic, focusing the study, and presenting a project outline. The first chapter of Elphinstone and Schweitzer's (1998) How to Get a Research Degree is especially relevant to writing a research proposal. Section headings in this chapter include "Choosing a thesis topic," "Defining your thesis topic," "Methodology and research design," "The research proposal," "Criteria for assessing a research proposal," and "Checklist of questions to be asked about a research proposal." Punch's (2006) Developing Effective Research Proposals is also a very good guide for writing research proposals. The final chapter of this book contains sample quantitative and qualitative research proposals. Paltridge and Phakiti's 2010) Continuum Companion to Research Methods in Applied Linguistics discusses approaches to research and areas of research that are of interest to people working the area of language teaching and learning. Finally, Thesis and Dissertation Writing in a Second Language (Paltridge \& Starfield, 2007) has a chapter titled "Writing a research proposal" which provides more detail on this process than has been given in this paper.

\section{Author Note}

Brian Paltridge, Faculty of Education and Social Work, University of Sydney.

Correspondence concerning this article should be addressed to Brian Paltridge, Faculty of Education and Social Work, The University of Sydney, NSW 2006, Australia. E-mail: brian.paltridge@sydney.edu.au 


\section{References}

Bell, J. (2010). Doing your research project: A guide for first-time researchers in Education and Social Science $\left(5^{\text {th }}\right.$ ed.). Buckingham, UK: Open University Press.

Elphinstone, L., \& Schweitzer, R. (1998). How to get a research degree: A survival guide. St Leonards, NSW, Australia: Allen \& Unwin.

Nakane, I. (2007). Silence in intercultural communication: Perceptions and performance. Amsterdam, Netherlands: John Benjamins.

Nunan, D. (1992). Research methods in language learning. Cambridge, UK: Cambridge University Press.

Paltridge, B., \& Phakiti, A. (2010). Continuum companion to research methods in applied linguistics. London, UK: Continuum.

Punch, K. (2006). Developing effective research proposals $\left(2^{\text {nd }}\right.$ ed.). London, UK: Sage.

Paltridge, B., \& Starfield, S. (2007). Thesis and dissertation writing in a second language. London, UK: Routledge.

Stevens, K., \& Asmar, C. (1999). Doing postgraduate research in Australia. Melbourne, Australia: Melbourne University Press. 